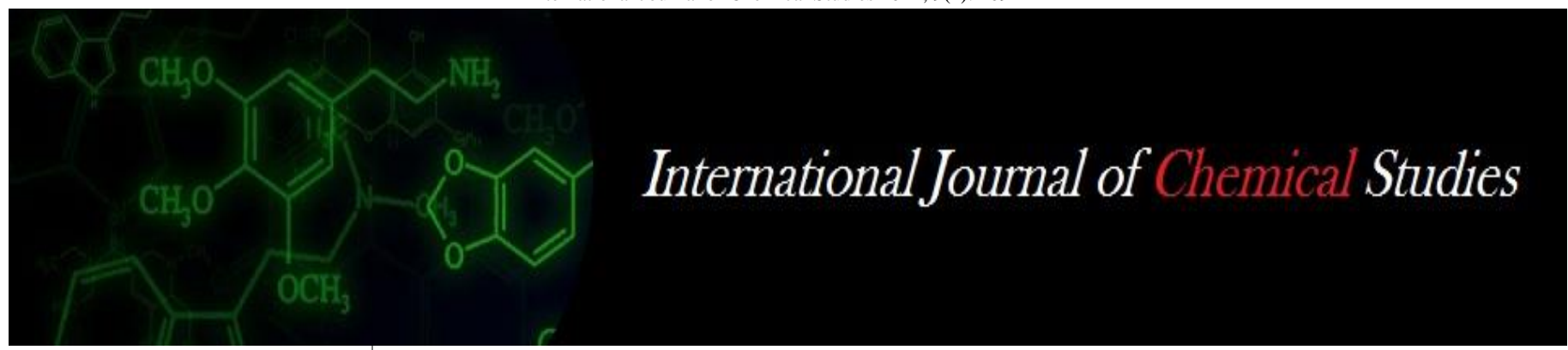

P-ISSN: 2349-8528

E-ISSN: 2321-4902

www.chemijournal.com

IJCS 2021; 9(1): 109-111

(C) 2021 IJCS

Received: 08-10-2020

Accepted: 27-11-2020

\section{Syed Khudus}

Department of Horticulture,

G.B. Pant University of

Agriculture and Technology,

Pantnagar, Uttarakhand, India

Ajit Kumar

Department of Horticulture,

G.B. Pant University of

Agriculture and Technology,

Pantnagar, Uttarakhand, India

\section{Non-conventional fertilizer sources for boosting flower production}

\section{Syed Khudus and Ajit Kumar}

\author{
DOI: $\underline{\text { https://doi.org/10.22271/chemi.2021.v9.i1b.11213 }}$
}

\begin{abstract}
Organic farming indicates a food production system where traditional wisdom and ancient knowledge of Indian agriculture such as crop rotations, mixed cropping, mixed farming, organic manuring, residue recycling, and agroforestry systems combine with modern practices of crop cultivation and livestock management to enhance profitability without dependence on off-farm resources The potential nonconventional fertilizers sources of plant nutrients are green manure crops, crop rotation, crop residues, organic manures, FYM, sludges, oilcake, blood meal, compost, phospho-compost, vermicompost, biogas slurry, agricultural wastes, press mud, Biodynamic preparations, bio-fertilizers, bio-enhancers, etc. (Sharma, 2004). In floriculture, organics are used as substrate media, as a component in plug plant production, in preparation of nursery for flower seeds, as a component for pot mixture for foliage plants, as essential media for greenhouse crops to improve the soil physical properties, as a soil drench of bulb soaking or foliar spray, in the propagation of ornamental crops, in the hardening of cultured tissue plants and as plant protection.
\end{abstract}

Keywords: Organic farming, non-conventional fertilizers, floriculture

\section{Introduction}

Organic farming means 'A food production system where traditional wisdom and ancient knowledge of Indian Farming such as crop rotations, mixed cropping, mixed farming, organic manuring, residue recycling, agroforestry systems are amalgamated with modern practices of crop cultivation and livestock management to enhance profitability without dependence on offfarm resources.' India blessed with various types of the naturally available organic form of nutrients, but the quality of these inputs needs to improve through Integrated Nutrient Management (INM), Integrated Pest Management (IPM), and Integrated Weed Management (IWM). Non- conventional fertilizers are those fertilizers manufactured using organic substances that are bio-degradable, i.e., non- conventional fertilizers are naturally occurring fertilizers and nutrient enhancers of the soil (Bokhtiar et al., 2005) ${ }^{[3]}$. Therefore, every substance that occurs naturally and is easily bio-degradable is organic, and if this organic material enhances the richness of the soil, it is termed as organic fertilizer. These organic substances are further decomposed and broken into smaller and soluble particles by numerous microorganisms. After being turned into soluble and simpler compounds, these fertilizers are taken in by the roots. Manure, slurry, worm castings, peat, seaweed, sewage, and guano are the naturally occurring. Green manure, compost, blood meal, bone meal and seaweed extracts, etc., are manufactured organic fertilizers. Crops are also grown to add nutrients to the soil. Today each farmer is looking forward to being a proper solution to the agricultural problems without compromising the yields. It is a universally acknowledged fact that organic fertilization methods are eco-friendly and fetch slower but steady results. In floriculture, organics are used as substrate media, as a component in plug plant production, in preparation of nursery for flower seeds, as a component for pot mixture for foliage plants, as essential media for greenhouse crops to improve the soil physical properties, as a soil drench of bulb soaking or foliar spray, in the propagation of ornamental crops, in the hardening of cultured tissue plants and as plant protection.

\section{Important non-conventional sources for ornamental plants}

Coco peat: Coco peat is a multi-purpose growing medium made out of coconut husk. Coco peat is an excellent alternative to traditional peat moss and Rock wool.
Syed Khudus

Department of Horticulture,

G.B. Pant University of

Agriculture and Technology,

Pantnagar, Uttarakhand, India 
It has air-filled porosity and high-water holding capacity and is an ideal growing medium for ornamental plants.

Vermiculite: This is a micaceous mineral produced by heating to $745{ }^{\circ} \mathrm{C}$. These are expanded plate-like particles having very high-water holding capacity, aeration and drainage.

Perlite: This is a siliceous mineral of volcanic origin. Perlite is rigid, sterile and nearly infertile with minimum CEC and neutral $\mathrm{p}^{\mathrm{H}}$. Perlite may be included in the mix to increase aeration and to lower bulk density. It is generally recommended for use in propagation media.

Sphagnum Moss: This is the dehydrated remains of acid bog plants from the genus Sphagnum. It is low in soluble salts, long-lasting in the mixture, uniform in the composition and improves drainage and aeration.

Vermicompost: It is prepared from the organic wastes upon the action of earthworms. It contains $2.5-3.0 \%$ Nitrogen, 1.0$1.5 \%$ Phosphorus and 1.5-2.0\% Potash.

Vermiwash: It is washings from the earthworms collected during the preparation of vermin-compost, used as a spray in raising of nursery, lawn and orchids. Vermiwash is rich in growth-promoting substances.

FYM/ Compost: It is prepared from the decomposition of organic wastes through anaerobic organisms. It contains a fair amount of macro and micro-nutrients and the most commonly used organic supplement given to flower crop cultivation. FYM contains $0.5-1.5 \% \mathrm{~N}, 0.4-0.8 \% \mathrm{P}_{2} \mathrm{O}_{5}$ and $0.5-0.9 \% \mathrm{~K}_{2} \mathrm{O}$ whereas Garden compost contains $0.5 \% \mathrm{~N}, 0.3 \% \mathrm{P}_{2} \mathrm{O}_{5}$ and $0.8 \% \mathrm{~K}_{2} \mathrm{O}$.

Panchagavya: Panchagavya is an organic product that can promote growth and provide immunity in the plant system. Panchagavya consists of nine products viz. cow dung, cow urine, milk, curd, jaggery, ghee, banana, Tender coconut and water. When suitably mixed and used, these have miraculous effects.
Jeevamrutha: A mixture of fresh desi cow dung and aged desi cow urine, jaggery, pulse flour, water and soil on farmland. Jeevamrutha is a fermented microbial culture that adds nutrients to the soil and acts as a catalytic agent to promote microorganisms and earthworms' activity in the soil. Jeevamrutha also helps to prevent fungal and bacterial plant diseases.

Green manures: Green manures include beans, peas, alfalfa, red clover, or cowpeas. They store nitrogen in nodules on the roots plant, fix nitrogen gas from the air, and combines it with hydrogen. This process creates ammonia, which is converted by bacteria into nitrates, a usable form of nitrogen; once the plants are tilled into the soil, they release the nitrogen into the earth. Green manures improve the soil and provide supplemental nitrogen removed by other plants' growth; they also help prevent soil erosion as they are used as cover crops.

Bone meal: Bone meal is finely ground bone, a by-product from animal slaughterhouses. It is an excellent source of calcium and contains up to $15 \%$ phosphate bone meal promotes healthy root systems and flowering. It is often used when growing flowers.

Blood meal: Blood meal is dried, powdered blood collected from cattle slaughterhouses. It's such a rich source of nitrogen that gardeners have to be careful not to over-apply and burn the roots of their plants. Apply blood meal just before planting to stimulate green leafy growth.

Bio-fertilizers: They are living organisms or preparations containing bio inoculants of efficient strains of microorganisms that help in the uptake of nutrients by converting unavailable forms of nutrients to available forms for plants use

Poultry manure: Poultry manure is the feces of chickens used as an organic fertilizer, especially for soil low in nitrogen of all animal manures; it has the highest amount of nitrogen, phosphorus, and potassium. One chicken produces approximately $8-11$ pounds of manure monthly

Table 1: Effect of non-conventional fertilizer sources in flower corps

\begin{tabular}{|c|c|c|c|c|}
\hline Sl. No & Crop & Fertilizer source & Effects & Reference \\
\hline 1 & Rose & $\begin{array}{l}\text { Poultry manure }(4 \mathrm{~kg} / \mathrm{m} 2)+\mathrm{NPK} 25, \\
20,15 \mathrm{~g} / \mathrm{m}^{2}+\mathrm{VAM}\end{array}$ & Increased plant growth and yield of flower & Singh et al., $2006^{[7]}$ \\
\hline 2 & $\begin{array}{l}\text { Chrysanthemum } \\
\text { cv. Little darling }\end{array}$ & $\begin{array}{c}\text { VAM (20 g/plant })+ \text { vermicompost } \\
\left(300 \mathrm{~g} / \mathrm{m}^{2}\right)\end{array}$ & $\begin{array}{c}\text { Vegetative and floral attributes of chrysanthemum cv. } \\
\text { Little Darling increased significantly }\end{array}$ & $\begin{array}{c}\text { Bohra and Ajit kumar } \\
2014^{[2]} \\
\end{array}$ \\
\hline 3 & $\begin{array}{l}\text { Chrysanthemum } \\
\text { cv. Dolly white }\end{array}$ & $\begin{array}{c}\text { Vermicompost }(2 \mathrm{t} / \mathrm{ha}) \text { and goat } \\
\text { manure }(25 \mathrm{t} / \mathrm{ha})\end{array}$ & $\begin{array}{c}\text { Recommended for commercial cultivation of } \\
\text { chrysanthemum }\end{array}$ & $\begin{array}{c}\text { Premkumar } \text { et al., } \\
2016^{[5]}\end{array}$ \\
\hline 4 & Gladiolus & VAM, vermicompost and vermiwash & Increased vegetative, floral and corm yield of gladiolus & Kumar et al., $2012^{[4]}$ \\
\hline 5 & Gerbera & Amended media $+20 \%$ vermiwash & Application increased overall performance of plant & Verma et al., $2013^{[9]}$ \\
\hline 6 & Anthurium & Sand and coir pit compost & Combination of this media increased vegetative growth & $\begin{array}{c}\text { Basheer and } \\
\text { Thekkayam 2012 }\end{array}$ \\
\hline 7 & Marigold & $\begin{array}{c}\text { Sand }+ \text { soil }+ \text { vermicompost }(1: 1: 2)+ \\
5 \% \text { biodynamic amendment }\end{array}$ & Growth and flowering increased in marigold & Singh et al., $2015^{[8]}$ \\
\hline
\end{tabular}

\section{References}

1. Basheer SN, Thekkayam SG. Effect of growing media and organic nutrition on vegetative growth in anthurium plants (Anthurium andreanum cv. Tropical). The Asian Journal of Horticulture 2012;7(2):354-358.

2. Bohra M, Ajit Kumar. Studies on effect of organic manures and bioinoculants on vegetative and floral attributes of chrysanthemum cv. Little Darling. The Bioscan 2014;9(3):1007-1010.

3. Bokhtiar SM, Sakurai K. Effects of organic manure and chemical fertilizer on soil fertility 2005.

4. Bokhtiar SM, Sakurai K. Effects of organic manure and chemical fertilizer on soil fertility and productivity of plant and ratoon crops of sugarcane. Archives of Agronomy and Soil Science 2005;51:325-334. 
5. Kumar P, Shekar C, Basoli M, Kumar V. Sequential spray of vermiwash at critical stages influences growth and quality in gladiolus cv. White Prosperity. Progressive Agriculture 2012;12(1):103-109.

6. okhtiar SM, Sakurai K. Effects of organic manure and chemical fertilizer on soil fertility 2005.

7. Premkumar A, Punetha P, Bohra M, Upadhyay S, Nautiyal BP. Response of chrysanthemum cultivar Dolly White to different sources and combinations of organic manures under the mid hill regions of Uttarakhand. International Journal of Agriculture Sciences 2016;8(59):3294-3297.

8. Sharma AK. A Handbook of Organic Farming. Agrobios, Rajasthan, India 2004.

9. Singh AK, Singh D, Jauhari S. Response of manures and bio-fertilizers on growth and flowering in rose. Journal of Ornamental Horticulrure 2006;9(4):278-281.

10. Singh M, Dwivedi DH, Kumar M. Efficiency of organic and biodynamic manures on growth and flowering in marigold (Tagetes patula L.). Progressive Agriculture 2015;15(1):134-137.

11. Verma AK, Sindhu SS, Janakiram T, Singh MC, Singh A, Singh B et al. Influence of vermi-products and Pusa Hydrogel on growth and flowering of landscape gerbera under greenhouse condition. International Journal of Agriculture, Environment and Biotechnology 2013;6(1):109-115. 